\title{
Predatory behavior of the land flatworm Notogynaphallia abundans (Platyhelminthes: Tricladida)
}

\author{
Maria E. T. Prasniski ${ }^{1} \&$ Ana M. Leal-Zanchet ${ }^{1,2}$
}

\author{
1 Programa de Pós-Graduação em Biologia, Universidade do Vale do Rio dos Sinos. Avenida Unisinos 950, 93022-000 São \\ Leopoldo, Rio Grande do Sul, Brasil. \\ 2 Corresponding author. E-mail: zanchet@unisinos.br
}

\begin{abstract}
Land flatworms are carnivorous, mainly predators. However, knowledge on their predatory behavior and prey preference is very scarce. This paucity of data is a limiting factor in the study of their biology and organismal ecology, resulting in a very difficult task to breed them in the laboratory for prolonged periods if prey preference and predation frequency are unknown. We investigated the predatory behavior of Notogynaphallia abundans (Graff, 1899), Geoplaninae, based on laboratory experiments. In order to determine its predatory choices, we offered mollusks, earthworms, arthropods, and other land flatworms. Only land isopods were accepted, with an average consumption of 3.4 individuals per week. Linear regression showed a positive relationship between the number of consumed isopods and the increase/decrease in body mass. Consumption resulting in an increase in body mass was ca. four isopods per week. Predatory behavior, with a mean time-span of $28 \mathrm{~min} 45 \mathrm{~s} \pm 15 \mathrm{~min} 47 \mathrm{~s}$, includes encounter and capture of prey, immobilization, handling and feeding. Variation in the duration of this activity in N. abundans is clearly due to variations in the time necessary for transferring the prey from either the anterior or posterior thirds of the body to the mouth, as well as for external digestion and ingestion. In order to capture very active and fast-moving animals such as land isopods, N. abundans employs various strategies, using either the anterior or the posterior body regions to press the prey against the ground or against its own body, thus allowing it to deal with various responses by the prey, and thereby maximizing predatory success. Similar to other flatworms, both physical holding and entrapment in a mucous secretion are of fundamental importance for prey-immobilization. The different strategies employed by land flatworms in their predatory behavior are discussed, and behavioral plasticity in the capture and immobilization of prey in different platyhelminth groups is emphasized.
\end{abstract}

KEY WORDS. Diet; isopods; planarians; prey preference; weekly consumption.

Land flatworms are carnivorous, preying upon slugs, snails, earthworms, nemerteans, land isopods, insect larvae, termites, springtails, mites and other arthropods, besides other land planarians (Du Bois-Reymond Marcus 1951, Froehlich 1955 , Dindal 1970, Ogren 1995, Jones \& Cumming 1998, Winsor et al. 1998, ОнвауASнi et al. 2005). Some species may feed on velvet worms, large insects and harvestmen (Graff 1899, Froehlich 1955, Carbayo \& Leal-Zanchet 2003).

The predatory behavior of land flatworms, combined with the fact that the recent distribution of some of them has been influenced by man, gives rise to concern about the possible impacts on prey populations (Blackshaw 1990, Ducey \& Noce 1998, Zaborski 2002, Ducey et al. 2005, Carbayo et al. 2007). The impacts of exotic predators on ecosystems may be determined by the invaders' predatory behavior, widely-foraging predators being able to cause heavy impact if they combine both tracking ability and the capacity to subdue prey in a wide range of microhabitats (FIORE et al. 2004). The now-cosmopolitan
Bipalium kewense Moseley, 1878 has been reported as being a threat to earthworm farms in the southern United States (WInsor 1983), the same occurring with Bipalium adventitium Hyman, 1943, which is now widely distributed throughout the northern portion of this country (Ducey \& Noce 1998, Fiore et al. 2004 Ducey et al. 2007). Platydemus manokwari Beauchamp, 1962, the "New Guinea flatworm", poses a threat for native land-snail populations, and may even be the cause of extinction of endemic species in certain Pacific countries (ОнвауASHI et al. 2005). Two other earthworm predators, Arthurdendyus triangulatus (Dendy, 1895) and Australoplana sanguinea alba (Dendy, 1891), respectively known as the "New Zealand flatworm" and the "Australian flatworm", have undergone rapid dispersion in certain European countries. At the time of discovery of their introduction, the biology of these species was practically unknown, thereby complicating any attempts to limit or slow down their human-mediated dispersal (AlFord et al. 1998). 
Flatworm locomotion is provided by means of extensive muscle layers and cilia, together with the secretion of mucus from subepidermal glands. Some species are able to move rapidly by means of peristaltic waves. They are able to lift the anterior region and execute twisting movements (BALL \& REYNOLDSON 1981, Froenlich 1955). Characteristics of the anterior body region as head musculature, mucous glands and chemical and tactile receptors are of fundamental importance for capturing prey (Ogren 1995). Predatory behavior in freshwater planarians has been well studied, whereas there are relatively few published observations on this topic in land flatworms (OGREN 1995). It must be added that knowledge on prey preference in land planarians is very poor. This paucity of data is a limiting factor in studying the biology and organismal ecology of land flatworms, resulting in a very difficult task to breed land planarians in the laboratory when both prey-preference and predation-frequency constitute unknown factors. Land flatworms seldom accepted meat or liver in the laboratory (Froenlich 1955), with only a few exceptions such as those reported by OGRen (1955) for Rhynchodemus sylvaticus (Leidy, 1851). Few studies have been undertaken under laboratory conditions, focusing on tracking, predatory behavior and success, and predation and growth rates, among others, and they were mainly restricted to A. triangulatus and B. adventitium (Blackshaw 1991, 1997, Ducey \& Noce 1998, YeAtes et al. 1998, Ducey et al. 1999, 2005, 2007, Christensen \& Mather 2001, ZaborsKi 2002, Fiore et al. 2004).

The present work was undertaken with the following objectives in view: (1) to determine prey preference and predation frequency of Notogynaphallia abundans (Graff, 1899) based on laboratory experiments, and (2) to analyze species predation behavior.

\section{MATERIAL AND METHODS}

Twenty specimens of N. abundans, between 20 and 40 $\mathrm{mm}$ long when extended, were collected from under fallen logs, leaves and bricks, in leaf litter or under other material on the ground, within fragments of native forest, and in gardens, in São Leopoldo, Brazil.

As its name suggests, N. abundans is an abundant species found in areas of semi-deciduous forest in the state of Rio Grande do Sul, in the northeastern region of Southern Brazil. It is also abundant in man-disturbed habitats, such as gardens and on the borders of small forest-fragments (A.M. Leal-Zanchet, unpubl. data). Adult specimens of N. abundans present an elongate body, which is ca. 30 to $60 \mathrm{~mm}$ long when crawling. The dorsum is yellowish, with seven dark-brown longitudinal stripes and many eyes distributed along the entire body-length. In adults, there are two openings on the ventral surface, the mouth and the gonopore, located, respectively, at the median and posterior thirds of the body (LEAL-ZANCHET \& Froehlich 2006).

Once in the laboratory, the flatworms were kept individually in terraria $(13.0 \times 6.6 \times 3.5 \mathrm{~cm}$ or $9.0 \times 5.5 \times 2.6 \mathrm{~cm}$, depending on the size of each specimen). Each terrarium contained moist soil and leaves and was sheltered from direct sun-light.

The first experiment lasted six months and focused on determining predatory choices of $N$. abundans. Based on the known diet of different species of flatworms, we offered snails: Bradybaena similaris (Férussac, 1821) and Helix aspersa (Müller, 1774); slugs: Deroceras sp.; earthworms: Pheretima hawayana (Rosa, 1891); isopods: Atlantoscia floridana (Van Name, 1940), Balloniscus sellowii (Brandt 1833), Benthana taeniata Araujo \& Buckup, 1994, Trichorhina tomentosa (Budde-Lund, 1893), and T. acuta Araujo \& Buckup, 1994; termites: Cryptotermes sp., Nasutitermes sp., and Apicotermitinae; insect larvae: Anticarsia gemmatalis Hübner, 1818 and Spodoptera frugiperda (Smith, 1797); and other land flatworms: Dolichoplana carvalhoi Correa, 1947, Rhynchodemus sp., Geoplana sp. 1 and Geoplana sp. 2. To test whether each potential prey would be accepted by $N$. abundans, one to four live animals from each taxon were placed inside each terrarium for a week, after which they were removed, having been monitored twice a week. When the preferential prey was identified, this was offered every two weeks, alternately with other potential prey items.

A second experiment, carried out during five weeks with 12 adult specimens of $N$. abundans, measuring between 30 and $70 \mathrm{~mm}$ long, consisted in offering an abundant food supply of isopods (ca. eight specimens per week) to each flatworm. Isopods offered to each flatworm measured between 5 and $8 \mathrm{~mm}$ in length, being not sorted by species. The terraria were prepared in the same way as described for the first experiment, and maintained in a cool room $\left(18-20^{\circ} \mathrm{C}\right)$ with a relative air-humidity of ca. $90 \%$. These were monitored weekly, the amount of exoskeletons of preyed isopods was counted, and additional isopods were released in the terrarium in order to reach the 8 available prey items at the beginning of a week. Skeletons could be distinguished from exuviae, since they were entire whereas the latter were fragmented (Araujo 1999). The body mass of each flatworm was recorded twice a week, with the animal placed on a moistened filter paper in a Petri dish, and by using a precision balance. Linear regression was used to verify the relationship between body mass and the number of preyed isopods, by means of Systat 11.0 (Systat Software Inc., Richmond, OR, USA).

To examine the predatory behavior, in order to describe mainly the phases from capture to feeding, three specimens of flatworms were used and five trials were conducted. For each trial, a flatworm and 2 to 5 isopods were placed together in a Petri dish with a slightly moistened bottom. The predatory events were recorded on video and subsequently described after computer analysis of the video records. Isopod exoskeletons were examined under the stereomicroscope.

\section{RESULTS}

The first experiment showed that $N$. abundans ubiquitously accepted all five species of land isopods as prey, and did not accept any other additional item offered. The second experiment showed that the mean weekly consumption of all flat- 
worms was 3.4 isopods with a maximum of eight isopods consumed per week and of 25 isopods consumed in five weeks. After five weeks, seven flatworms, which eat an average of 4.1 isopods per week, presented an average increase of $21.3 \mathrm{mg}$ in body mass, which corresponds to $34.2 \%$ of the average body mass of those specimens. Five flatworms, which consumed an average of 3.0 isopods per week, showed an average decrease of $42.0 \mathrm{mg}$ in body mass, corresponding to $-43.3 \%$ of their average body mass. There was a positive relationship $\left(\mathrm{r}^{2}=0.52, \mathrm{~F}=10.816\right.$, d.f. $=1,10, \mathrm{p}=0.008$ ) between the number of preyed isopods and the increase/decrease in body mass (Fig. 1).

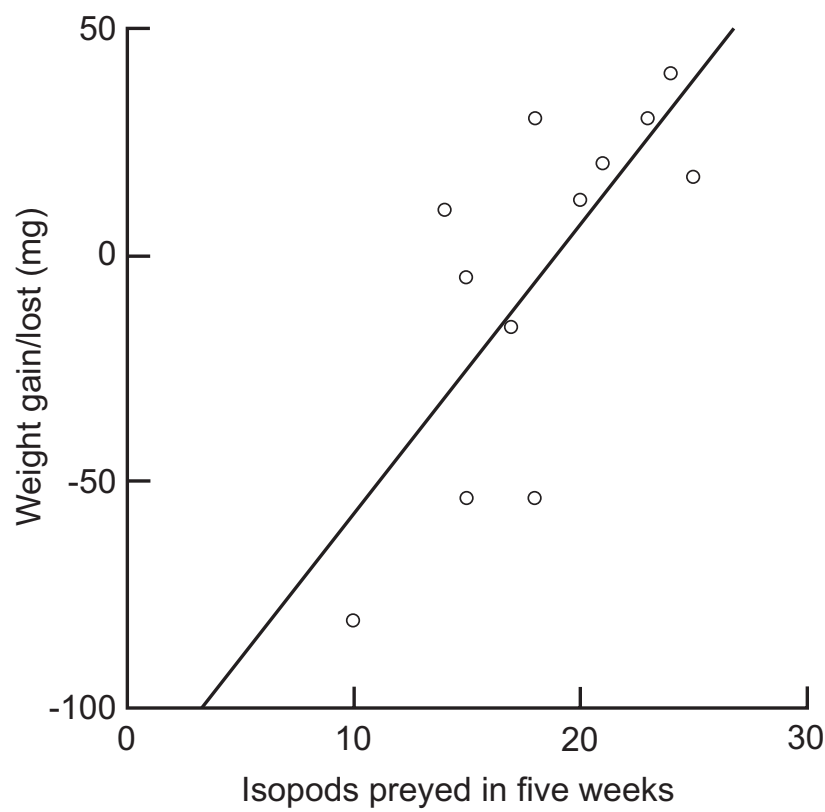

Figure 1. Linear regression showing the relationship between body mass and the amount of consumed isopods of 12 specimens of Notogynaphallia abundans (Graff 1899) over a five-week-period.

The predatory behavior of N. abundans includes the encounter, capture and immobilization of prey, bringing the prey to the level of the pharynx, and feeding. The trials conducted to examine this behavior showed a mean time span between capture and end of feeding of ca. $28 \min 45 \mathrm{~s} \pm 15 \mathrm{~min} 47 \mathrm{~s}$ (mean \pm S.D., $\mathrm{n}=5$ ).

\section{Locating prey}

The flatworm crept with the anterior extremity raised and waving slightly from side to side showing sensory behavior. In some observations on the process, the isopod, when exploring the environment, collided with the anterior or median regions of the body of the flatworm (Figs 2, 6-7 and 10), and was then very quickly captured (see below). In other observations, the isopod moved close to the anterior extremity or the median region of the body of the flatworm, touching it softly (Figs 14-16), then being quickly captured. In another observation, the isopod moved to the side of the planarian, apparently touching it slightly (Figs 21 and 22). Muscular wavemovements were observed on the margin of planarian body, and when the isopod was at the level of the posterior third of the planarian body, it was captured.
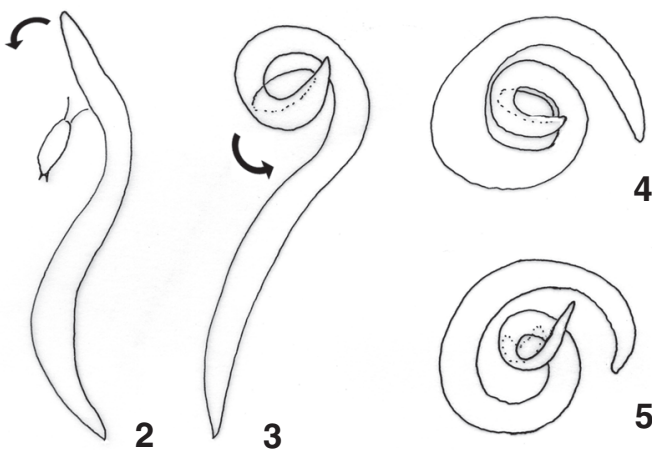

4
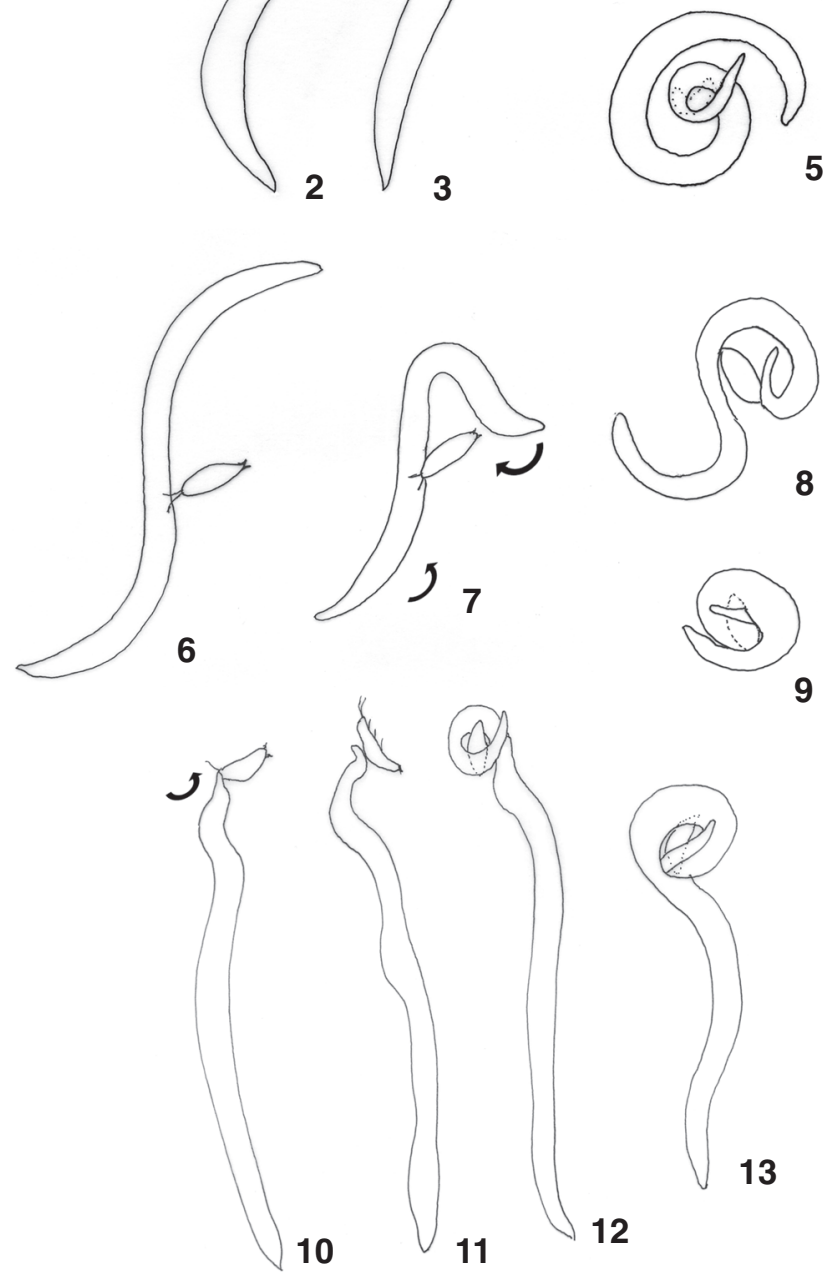

Figures 2-13. Three redatory events in which a specimen of $N$. abundans has captured the prey with the anterior third of the body $(2-5,6-9)$ or with the anterior tip (10-13): $(2,6-7,10)$ locating prey; $(3,8,11)$ capture; $(4-5,9,12-13)$ immobilization of prey. Arrows show the direction of movement. In (2, 6, and 10), the anterior end of the flatworm is towards the top of the picture. 


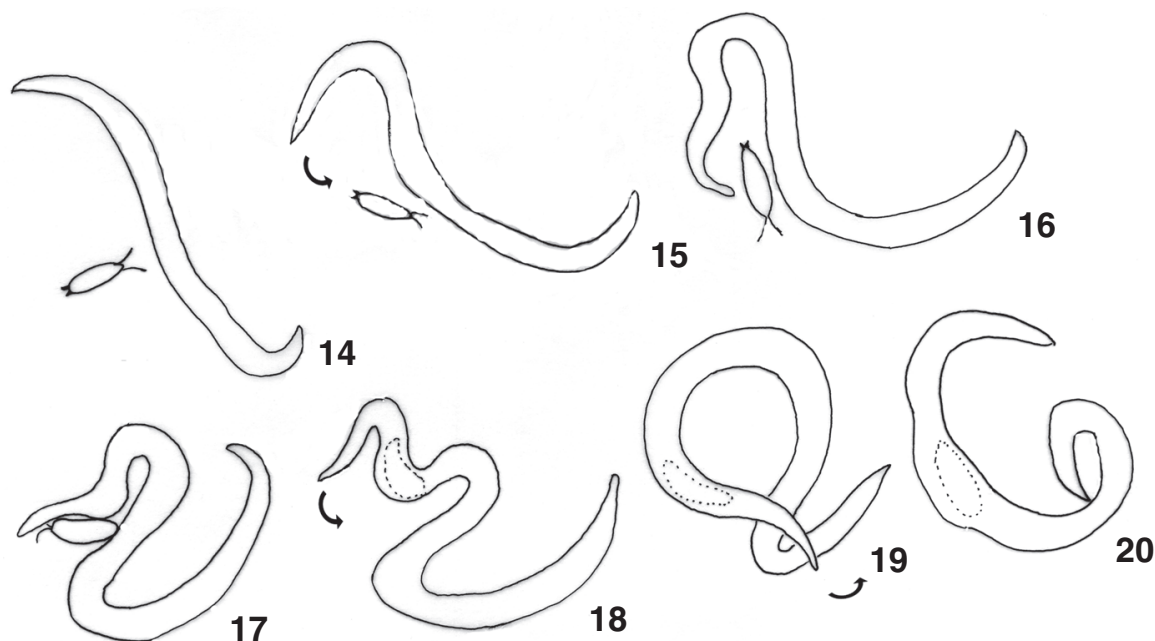

17

18
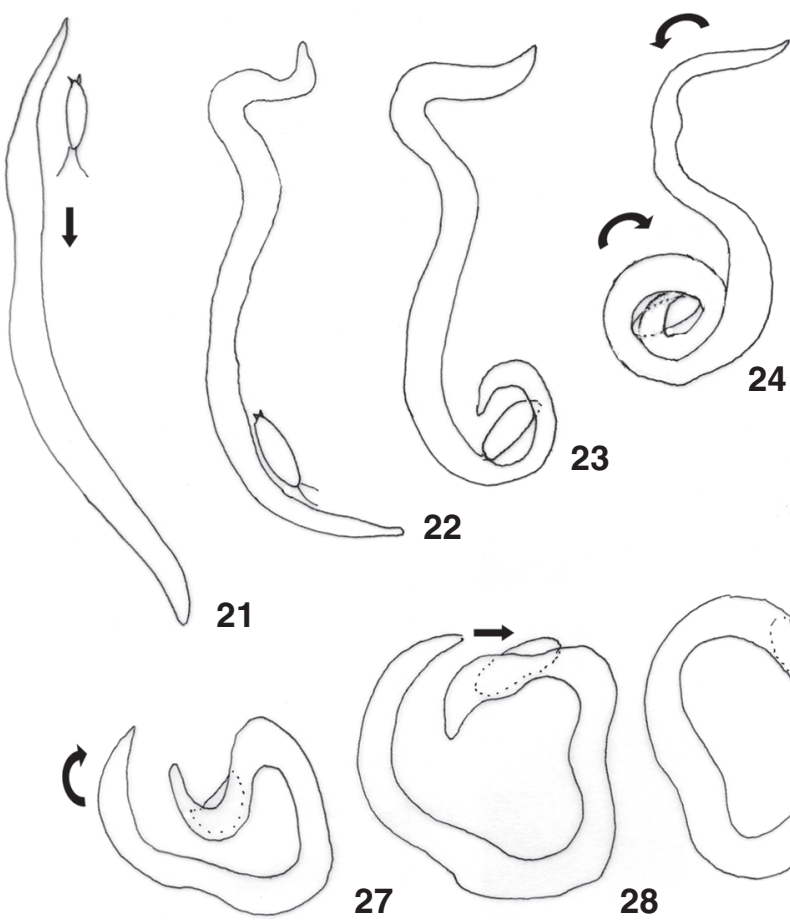

23

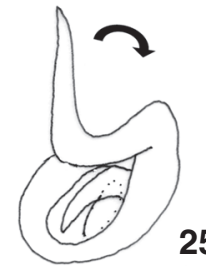

25

22

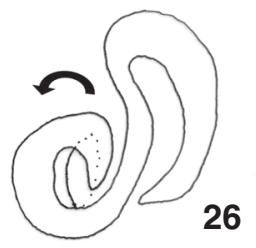

Figures 14-30. Two predatory events in which prey-capture occurred by pressing it against the median region of the planarian body itself (14-20) or by means of the posterior third of the body of Notogynaphallia abundans (Graff 1899) (21-30): (14-16, 21-22) locating prey; $(17,23)$ capture; $(18,24-25)$ immobilization of prey; $(19,26-29)$ bringing the prey to the level of the pharynx; $(20,30)$ feeding. Arrows show the direction of movement. In (14 and 21), the anterior end of the flatworm is towards the left side of the picture.

\section{Capture}

Prey capture was achieved by quickly moving the anterior or posterior region onto the prey, immediately enveloping it (Figs 3 and 23). During entrapment the ventral surface of the flatworm made initial contact with the dorsum or side of the prey, pressing it against the substratum or against the median region of the pla- narian body (Figs 8 and 17). In order to hold the prey against its body, the flatworm bent the anterior or the posterior third of the body laterally, so that the ventral surface was perpendicular to the ground. Another type of capture was performed with the anterior region (ca. 1/5 of the body length) rapidly encircling the prey, so that it was lifted from the ground (Fig. 11). 


\section{Immobilizing the prey}

The planarian coiled approximately either the anterior or the posterior third of its body around the prey (Figs 4-5, 12-13 and 24-25), according to the part of the body used for capture, whilst maintaining its ventral surface perpendicular to the ground, or used its body either to encircle the prey in a spiral (Fig. 9) or to press the prey against the substratum (Fig. 18). At the same time, a considerable amount of mucus was secreted over the prey, which was usually seen twitching its legs, being soon immobilized. The time for immobilizing the prey ranged from 6 to 24 seconds ( $12.8 \mathrm{~s} \pm 7.7 \mathrm{~s}$, mean \pm S.D., $\mathrm{n}=5$ ).

\section{Bringing the prey to the level of the pharynx}

When capture was achieved using the anterior portion of the body, after immobilizing the prey, the flatworm turned the ventral surface to the ground and glided over the prey (Fig. 19), until the prey was at the level of the mouth, which is located on ventral surface approximately at the end of the median third of the body. When capture occurred with the posterior extremity, after immobilizing the prey, the flatworm, bending the body posteriorly, gradually moved the anterior extremity towards the prey, freeing the posterior end to regain contact with the ground (Figs 26-28). Afterwards, the flatworm crept over the prey (Fig. 29) to bring it into contact with its mouth. The time for bringing the prey to the mouth ranged from $10 \mathrm{~s}$ to $2 \mathrm{~min} 42 \mathrm{~s}$ ( $1 \mathrm{~min}$ $31 \mathrm{~s} \pm 1$ min $6 \mathrm{~s}$, mean \pm S.D., $\mathrm{n}=5$ ), with median of 2 min3s.

\section{Feeding}

For external digestion and subsequent ingestion of prey tissues, the flatworm kept the body in a hairpin or S-shaped bend, with the median third of the body flattened (Figs 20 and 30). It stayed motionless while it sucked the prey, although the anterior end sometimes made slow side-to-side movements. During this process, the flatworm was observed to change position probably in order to have access to other parts of the prey's body. The time for external digestion and ingestion ranged from $12 \mathrm{~min} 50 \mathrm{~s}$ to $51 \mathrm{~min} 20 \mathrm{~s}(27 \mathrm{~min} \pm 14 \mathrm{~min} 50 \mathrm{~s}$, mean \pm S.D., $n=5$ ), with median of 25 min 7 s. Examination of the isopod exoskeleton after being sucked showed that the ventral surface of the isopod body is ruptured, and that the soft tissues had been consumed with the exception of the intestine, which remained with the exoskeleton.

\section{DISCUSSION}

Land isopods have previously been reported as prey of six species of land planarians: Notogynaphallia ernesti Leal-Zanchet \& Froehlich, 2006, N. caissara (Froehlich, 1955), Pasipha tapetilla (Marcus, 1951), Enterosyringa pseudorhynchodemus (Riester, 1938), Caenoplana coerulea vaga (Hyman, 1943) and Parakontikia ventrolineata (Dendy, 1892) (Froenlich 1955, Olewine 1972, Barker 1989). Nevertheless, prey-species were not identified in these studies. Similar to observations by BLACKSHAW \& STEWART (1992) for Arthurdendyus triangulatus and Ducey \& Noce (1998) for Bipalium adventitium, both of which prey on several species of earthworms, N. abundans ate specimens of all the five species of land isopods offered in our experiment. However, N. abundans did not accept any other of the potential prey items. In the case of some land flatworm species, there are reports about predation on animals of very different taxonomic groups, although many species show prey preference (OGREN 1995), thus presenting a narrow diet-range. According to MacArthur \& PiAnKa (1966), diet-width is determined by the choices made by predators once they have encountered prey, and which are ultimately determined towards maximization of profitability for the predator. Regarding the diet-range of land flatworms, we are far from understanding their degree of specialization.

There is little available data in the literature concerning predation-frequency and gain in body mass of land planarians in experimental studies. Once prey preference has been defined, laboratory-maintenance of land flatworms depends on knowing the minimum consumption leading to growth. In the present case, and in spite of the constant and abundant food supply for each specimen of $N$. abundans, some failed to prey on enough isopods to allow growth. We cannot exclude the possibility that at least some of these specimens came from field parasitized or even diseased which may have interfered with the results obtained. Nevertheless, future experiments should test attack behavior and predatory success in $N$. abundans in relation to prey size and different prey species, as well as the influence of consuming distinct isopod prey species on the mass gained.

Concerning the duration of predatory behavior, $N$. abundans needs as much time as M. termitophaga for eating termite soldiers, which, in turn, was longer than that required for eating workers (Jones \& CUMming 1998). These authors divided the feeding process into three phases: the time necessary for subduing the termite, including transferring the prey to the pharynx; that for the termite to die; and that for completing both digestion and ingestion. They commented that variations in the time-span for feeding seems either to result from variations in handling times or the time to die, or both, rather than in the time for digestion. Variation in the duration of predatory behavior of N. abundans is clearly due to variations in the time for transferring the prey from the anterior or posterior thirds of the body to the mouth, as well as for external digestion and ingestion, rather than in the time spent in capture and immobilization. Knowledge on the predatory behavior of flatworms is very scarce, thus hindering comparison of strategies used for predation of the different prey-types. This knowledge could provide valuable data towards a better understanding of the evolution of predatory behavior in flatworms.

Land flatworms seem to manifest oriented-search behavior to locate prey, as was demonstrated by FIORE et al. (2004) for Bipalium adventitium, which detects and follows chemical trails from earthworms. In the present work, we did not investigate the behavior for locating prey. The ability to search for and track prey and the role of chemo-receptors in the process of prey location remain open topics for most land flatworm species. 
Some flatworms present cephalic specialization for preycapture (Froehlich 1955, Ogren 1995). Notogynaphallia abundans, which, at least externally, does not denote morphological specialization of the anterior extremity (Leal-Zanchet \& Froehlich 2006), employs various strategies for capturing isopods, using not only the anterior but also the posterior body-region, by pressing the prey against the ground or against its own body. This flatworm can also encircle the prey and lift it from the ground by using the anterior body region, thereby preventing escape. This behavior was also observed for species with cephalic specialization, such as Rhynchodemus spp. and Bipalium cf. vagum Jones \& Sterrer, 2005, respectively, for catching springtails and slugs (Froenlich 1955, Ogren 1995, Ducey et al. 2007). The different strategies employed by $N$. abundans in the capture of very active and fast-moving animals such as land isopods allows for adaptation to various responses by the prey, thereby maximizing its predatory success.

Notogynaphallia abundans also prevents prey-escape by quick immobilization, involving and pressing the relatively small isopod body, at the same time secreting an abundant amount of mucus so that the prey becomes still some seconds after capture. For certain larger prey-types, immobilization takes place at a later time in predatory behavior, when digestive fluids are released through the flatworm pharynx (JENNINGs 1959, Dindal 1970, Ogren 1995). In B. adventitium, this may be complemented by "capping" behavior of the anterior body regions of the prey, followed by cessation of its violent struggling (DuceY et al. 1999). Despite the diverse strategies used by different flatworm species, according to prey size and nimbleness, both physical holding and entrapment in a mucous secretion have been indicated as being of fundamental importance for immobilizing prey (JenNings 1959, Ogren 1995, Jones \& Cumming 1998, FioRe et al. 2004).

Regarding feeding-mode, Froenlich (1955) commented that arthropods preyed upon by different species of land flatworms were not swallowed but sucked, there remaining only the empty or nearly empty exoskeleton, and, in the case of isopods, only the dark gut, similar to our observations on $N$. abundans. The feeding-mode and the role of the pharynx in capture and immobilization are related to the type of pharynx and prey. Species which have a bell-shaped or collar-type pharynx spread this organ over the prey, as described by DINDAL (1970) for B. adventitium, whereas a cylindrical-type pharynx must be extended into the prey through the body wall to suck internal tissues. To feed on isopods which possess a strong, dorsally thicker exoskeleton, the bell-shaped type of pharynx of N. abundans (Leal-Zanchet \& Froehlich 2006) appears to be involved in the rupture of the ventral exoskeleton, thus gaining access to internal tissues. The release of digestive fluids by the pharynx is important in external digestion for sucking liquefied tissues.

Notogynaphallia abundans presented diverse strategies for capturing and immobilizing prey. A similar plasticity in preda- tory behavior, thereby enabling predator adaptation to various prey-responses, has also been demonstrated in polyclads and rhabdocoels by Koopowitz et al. (1976) and Wrona \& Koopowitz (1998). Here we demonstrated plasticity in an additional group of flatworms, suggesting such plasticity may be wide-spread.

\section{ACKNOWLEDGMENTS}

The authors thank Eudoxia Froehlich, Leigh Winsor, and two anonymous referees for suggestions and comments on an early draft of the manuscript. Aline Vizeu, Vanessa Baptista, and Welcy Santos are acknowledged for their help with collecting and maintaining specimens in the laboratory. Daniela Florencio, Fernando Santos, Ingrid Heyrich, Luciano Moura, and Marcelo Barros were thanked for the identification of the invertebrates offered to the flatworms. Ramon Clark and Edward Benya are acknowledged for the English revision of the manuscript. Thanks are also due to Paulo Prasniski, Vanessa Baptista, and Fabiano Gil for their help with image capture and preparation of the final version of the figures.

\section{REFERENCES}

Alford, D.V.; B.Boag; P.M. Johns \& G.W. Yeates. 1998. Report on the OECD Workshop on terrestrial flatworms. Pedobiologia 42: 385-388.

Araujo, P.B. 1999. Subordem Oniscidea (Isópodos terrestres, "tatuzinhos"), p. 237-256. In: L. Buckup \& G. Bond-Buckup (Eds). Os crustáceos do Rio Grande do Sul. Porto Alegre, UFRGS, 503p.

Ball, I.R. \& T.B. Reynoldson. 1981. British Planarians. Cambridge, Cambridge University Press, 125p.

BARKER, G.M. 1989. Flatworm predation of terrestrial molluscs in New Zealand and a brief review of previous records. New Zealand Entomologist 12: 75-79.

BlackshaW, R.P. 1990. Studies on Artioposthia triangulata (Dendy) (Tricladida: Terricola), a predator of earthworms. Annals of Applied Biology 116: 169-176.

BlaCKSHAW, R.P. 1991. Mortality of the earthworm Eisenia fetida (Savigny) presented to the terrestrial planarian Artioposthia triangulata (Dendy) (Tricladida: Terricola). Annals of Applied Biology 118: 689-694.

Blackshaw, R.P. 1997. The planarian Artioposthia triangulata (Dendy) feeding on earthworms in soil columns. Soil Biology and Biochemistry 29: 299-302.

Blackshaw, R.P. \& V.I. Stewart. 1992. Artioposthia triangulata (Dendy) (Tricladida: Terricola), a predatory terrestrial planarian and its potential impact on lumbricid earthworms. Agricultural Zoology Review 5: 201-219.

Carbayo, F. \& A.M. Leal-Zanchet. 2003. Two new genera of geoplanid land planarians (Platyhelminthes: Tricladida: Terricola) of Brazil in the light of cephalic specialisations. Invertebrate Systematics 17: 449-468. 
Carbayo, F.; J Pedroni \& E.M. Froehlich. 2007. Colonization and extinction of land planarians (Platyhelminthes, Tricladida) in a Brazilian Atlantic Forest regrowth remnant. Biolological Invasions 10: 1131-1134.

Christensen, O.M. \& J.G. Mather. 2001. Long-term study of growth in the New Zealand flatworm Arthurdendyus triangulatus under laboratory conditions. Pedobiologia 45: 535-549.

Dindal, D.L. 1970. Feeding behavior of a terrestrial turbellarian Bipalium adventitium. American Midland Naturalist 83: 635-637.

Du Bors-Reymond Marcus, E. 1951. On South American geoplanids. Boletim da Faculdade de Filosofia, Ciências e Letras da Universidade de São Paulo, Série Zoologia, 16: 217-255.

Ducey, P.K. \& S. Noce. 1998. Succesful invasion of New York state by the terrestrial flatworm, Bipalium adventitium. Northeastern Naturalist 5 (3): 199-206.

Ducey, P.K.; M. Messere; K. LaPoint \& S. Noce. 1999. Lumbricid prey and potential hepetofaunal predators of the invading terrestrial flatworm Bipalium adventitium (Turbellaria: Tricladida: Terricola). American Midland Naturalist 141: 305-314.

Ducey, P. K.; L-J. West; G. ShaW \& J. DeLisle. 2005. Reproductive ecology and evolution in the invasive terrestrial planarian Bipalium adventitium across North America. Pedobiologia 49: 367-377.

Ducey, P.K.; M. McCormick \& E. DAvidson. 2007. Natural history observations on Bipalium cf. vagum Jones and Sterrer (Platyhelminthes: Tricladida), a terrestrial broadhead planarian new to North America. Southeastern Naturalist 6(3): 449-460.

Fiore, C.; J.L.Tull; S. Zehner \& P.K. Ducey. 2004. Tracking and predation on earthworms by the invasive terrestrial planarian Bipalium adventitium (Tricladida, Platyhelminthes). Behavioural Processes 67: 327-334.

Froenlich, C.G. 1955. On the biology of land planarians. Boletim da Faculdade de Filosofia, Ciências e Letras da Universidade de São Paulo, Série Zoologia, 20: 263-271.

Graff, L. von. 1899. Monographie der Turbellarien. II. Tricladida Terricola. Leipzig, Engelmann. 574p.

JEnnings, J.B. 1959. Observations on the nutrition of the land planarian Orthodemus terrestris (O. F. Müller). Biological Bulletin 117: 119-124.

Jones, H.D. \& M.S. Cumming. 1998. Feeding behaviour of the termite-eating planarian Microplana termitophaga (Platyhelminthes: Turbellaria: Tricladida: Terricola) in Zimbabwe.
Journal of Zoology 245: 53-64.

Koopowitz, H.; D. SiLver \& G. Rose. 1976. Primitive nervous systems. Control and recovery of feeding behavior in the plolyclad flatworm, Notoplana acticola. Biological Bulletin 150: 411425.

Leal-Zanchet, A.M. \& E.M. Froehlich. 2006. A species complex in the genus Notogynaphallia Ogren and Kawakatsu (Platyhelminthes: Tricladida: Terricola) with a taxonomic revision of homonyms of Geoplana marginata Schultze \& Müller and a reinterpretation of Notogynaphallia caissara (Froehlich) anatomy. Belgian Journal of Zoology 136: 81100 .

MacArthur, R.H. \& E.R. Pianka. 1966. On optimal use of a patchy environment. American Naturalist 100: 603-609.

Ogren, R.E. 1955. Ecological observations on the occurrence of Rhynchodemus, a terrestrial turbellarian. Transactions of the American Microscopical Society 74: 54-60.

Ogren, R.E. 1995. Predation behaviour of land planarians. Hydrobiologia 305: 105-111.

Ohbayashi, T.; I. ОколHi; H. SATo \& T.Ono. 2005. Food habit of Platydemus manokwari De Beauchamp, 1962 (Tricladida: Terricola: Rhynchodemidae), known as predatory flatworm of land snails in the Ogasawara (Bonin) Islands, Japan. Applied Entomology and Zoology 40: 609-614.

Olewine, D.A. 1972. Further observations in Georgia on the land planarians, Bipalium kewense and Geoplana vaga (Turbellaria: Tricladida: Terricola). Association of Southeastern Biologists Bulletin 19: 88.

Winsor, L. 1983. A revision of the cosmopolitan land planarian Bipalium kewense Moseley, 1878 (Turbellaria: Tricladida: Terricola). Zoological Journal of the Linnean Society 79 : 61-100.

Winsor, L.; P.M. Johns \& G.W. Yeates. 1998. Introduction, and ecological and systematic background, to the Terricola (Tricladida). Pedobiologia 42: 389-404.

Wrona, F.J. \& H Koopowitz. 1998. Behavior of the rhabdocoel flatworm Mesostoma ehrenbergii in prey capture and feeding. Hydrobiologia 383: 35-40.

Yeates, G.W.; B. Boag \& P.M. Johns. 1998. Field and laboratory observations on terrestrial planarians from modified habitats in New Zealand. Pedobiologia 42: 554-562.

ZABorski, E.R. 2002. Observations on feeding behavior by the terrestrial flatworm Bipalium adventitium (Platyhelminthes, Tricladida, Terricola) from Illinois. American Midland Naturalist 148: 401-408.

Submitted: 21.XI.2008; Accepted: 23.XI.2009.

Editorial responsability: Pedro Gnaspini Netto 